\title{
TOPRAĞA GÖMEREK VEYA BUZDOLABI KOŞULLARINDA OLGUNLAŞTIRMANIN SIVAS KÜP PEYNİIINİN ÖZELLİKLERİ ÜZERİNE ETKİSİ
}

\author{
Dilşat Bulut Ergin ${ }^{1,2}$, Nurcan Koca ${ }^{1 *}$ \\ ${ }^{1}$ Ege Üniversitesi, Mühendislik Fakültesi, Gıda Mühendisliği Bölümü, İzmir, Türkiye \\ ${ }^{2}$ Tarım ve Kırsal Kalkınmayı Destekleme Kurumu, Balıkesir İl Koordinatörlügüü, Balıkesir, Türkiye
}

Geliş / Received: 04.09.2018; Kabul / Accepted: 29.01.2019; Online bask1 / Published online: 13.03.2019

Bulut Ergin, D. Koca, N. (2019). Toprağa gömerek veya buzdolabı koşullarında olgunlaştırmanın Sivas Küp peynirinin özellikleri üzerine etkisi. GIDA (2019) 44 (2): 248-259 doi: 10.15237/gida.GD18094

Bulut Ergin, D. Koca, N. (2019). The effects of ripening of Sivas Kup (jar) cheese storing under refrigerated conditions or being burried in the soil. GIDA (2019) 44 (2): 248-259 doi: 10.15237/gida.GD18094

\section{ÖZ}

Bu çalışmada, geleneksel olarak uygulanan toprağa gömülerek olgunlaştırma ile son ylllarda yaygınlaşan buzdolabı koşullarında olgunlaştırmanın, Sivas Küp peynirinin bileşimi, lipoliz ve olgunlaşma düzeyi, maya ve küf sayısı ile duyusal özellikleri üzerine etkilerinin kıyaslanması amaçlanmıştır. Toprakta olgunlaştırılan peynirlerin olgunlaşma süresince kurumadde, yağ ve protein değerleri buzdolabında olgunlaştırılanlara nazaran daha yüksek, tuz içerikleri ise daha düşük seyretmiştir. Ayrıca, toprakta olgunlaştırılan peynirlerin serbest yağ asitliği değerleri ile olgunlaşma düzeyleri daha yüksek tespit edilmiştir. Üretim sonrasında peynir örneklerinin maya ve küf sayıları 3.81 $\pm 0.19 \mathrm{log} \mathrm{kob} / \mathrm{g}$ olarak belirlenmiştir. Olgunlaşmanın 15. gününde, buzdolabı koşullarında olgunlaştırılan peynire kıyasla, toprakta olgunlaştırlan peynirin maya ve küf sayısında daha fazla bir artış tespit edilmiş ve bu durum topraktan peynire bulaşma olduğunun göstergesi olarak değerlendirilmiştir. Olgunlaşma süreci sonunda yapılan duyusal değerlendirmede, her iki peynir grubu da iyi derecede duyusal puanlar almasına karşıı; görünüş, doku ve tüm izlenim açısından toprakta olgunlaştrilan peynirler nisbeten daha yüksek puanlar almıştır.

Anahtar kelimeler: Sivas Küp peyniri, olgunlaşma, toprak, maya ve küf sayıs1, buzdolabı koşulları

\section{THE EFFECTS OF RIPENING OF SIVAS KUP (JAR) CHEESE STORING UNDER REFRIGERATED CONDITIONS OR BEING BURRIED IN THE SOIL}

\begin{abstract}
In this study, it was aimed to compare the composition, lypolizis and ripening level, mold and yeast count and sensory properties of Sivas Küp cheeses ripened under refrigerated conditions as a recent method or ripened being buried in the soil as a traditional method. The dry matter, fat and protein contents were higher, but the salt content was lower in the cheese ripened in the soil than those of the cheese ripened under the refrigerated conditions. In addition, the free fatty acid values and ripening indexis of cheeses ripened under soil were found high. After production, yeast and mold count of unripened cheese was $3.81 \pm 0.19 \mathrm{log} \mathrm{cfu} / \mathrm{g}$. On the 15 th day of ripening, a greater increase in the number of yeast and mold of cheese ripened in the soil compared to that of the cheese ripened in the refrigerated conditions was determined and this was assessed as an indication of cheese contamination from the soil. At the end of the ripening period, both cheese groups received good sensory scores, but the cheeses ripened in the soil in terms of appearance, texture and overall impression received relatively higher scores.
\end{abstract}

Keywords: Sivas Küp cheese, ripening, soil, yeast and mould count, refrigerated conditions

* Yazışmalardan sorumlu yazar / Corresponding author;

E-posta: nurcan.koca@ege.edu.tr Tel: (+90) 2323113029

Faks: (+90) 2323427592 


\section{GİRİ̧̧}

Son y1llarda, yöresel peynirlerin üretildiği bölgelerin dışında, özellikle büyük şehirlerde de aranır hale gelmesi, üretimlerinin artmasina neden olmuştur. $\mathrm{Bu}$ peynirlerin mevcut durumlarının saptanması ve kontrollü koşullarda üretimlerinin gerçekleştirilebilmesi için çalışmaların yapılması, ülke ekonomisine kazandırılması açısından önem arz etmektedir. Yöresel peynirler arasında olan küp peyniri, İç Anadolu ve Doğu Anadolu bölgesinde, hemen hemen tüm illerde geleneksel olarak üretilen bir peynir çeşididir. Bazı illerde üretilen çömlek veya testi peyniri ile de benzerdir.

Sivas ve ilçelerinde yaygın olarak üretilen Sivas küp peyniri, peynir mayas ilavesi ile elde edilen ve olgun olarak tüketilen oldukça aromatik ve lezzetli bir peynir çeşididir. Köylülerden alınan bilgilere göre, küp peyniri nisan-ekim ayları arasında tam yağlı ya da kısmen yağ1 alınmış inek sütünden üretilmektedir. Çiğ sütten enzim ilavesi ile pihtıştırilmakta ve sonrasında peynir suyunun çıkmasını kolaylaştırmak amaciyla, bıçakla geniş aralıklarla kesim yapilmakta ve $50^{\circ} \mathrm{C}$ lere 1sitılmaktadır. Küp peynirlerinde genel olarak haşlama suyu sıcaklığı farklı kaynaklarda 52-80 C olarak bildirilmektedir (Güven ve Karaca, 2004; Pekel ve Korukoğlu, 2009; Kamber ve Terzi, 2008). Pihtınin 1sitilmasi sonrasinda pihtı peynir suyunun süzülmesi için torbalara doldurulmakta ve yöresel olarak taşlar ile baskı uygulanmaktadır. Elde edilen peynir küçük kalıplar halinde kesildikten sonra tuzlanmakta ve kalıplar halinde küp/kavanoza yerleştirilmektedir. Geleneksel olarak olgunlaşma sırasında ambalaj olarak küpler kullanılmasına karşın, günümüzde kolay bulunabilir ve ucuz olması nedeniyle Sivas küp peyniri plastik kavanozlarda olgunlaştırılmaktadır. Dolum sonrasında kalıp aralarındaki boşlukları gidermek için, çökelek, lor bazen de küp peyniri yapımı için üretilen peynirin kendisi ufalanarak kalıplar arasına doldurulmaktadır. Olgunlaştırma işlemi, köylerde geneleneksel olarak peynirle dolu kavanozun ağzı bir bezle kapatıldıktan sonra, ağız kısmı aşağıya gelecek şekilde ters çevrilip ya tamamı ya da yarısı toprağa gömülerek sağlanmaktadır. Tamamının gömülmesi durumunda sicaklık peynirin her yerinde eşit olarak sağlanabilmektedir. Son yllarda ise buzdolabı koşullarında veya soğuk hava depolarında peynir kavanozlarının ağızları delinip ters çevrilerek saklanması tercih edilen bir yöntem haline gelmiştir. Peynirden ayrlan suyu uzaklaştırmak içinse kavanozun altına suyu çekecek bezler konulmakta ve zaman zaman bezlerdeki fazla su uzaklaştırlmaktadır. Küp peynirlerinin üretimleri temelde benzemesine karşın, diğer yörelerde üretilen küp peynirlerin üretimleri, Sivas küp peynirinin üretimi ile bazı açılardan farkll1ık göstermektedir. Örneğin, toprağa gömülerek olgunlaştırılan Hatay iline özgü Carra peynirinin üretim aşamalarında peynirler testi veya PET (polietilen tereftalat) kavanozlara basılmadan önce, çökelek, çörekotu ve kekik karışımından hazırlanan harçla karıştırılmaktadır (Güler, 1999).

Sivas küp peyniri ile yapılan çalışmalar oldukça sinırlıdır. Pekel ve Korukoğlu (2009), Sivas yöresinden sağlanan 25 adet küp peynirinde kimyasal ve mikrobiyolojik analizler gerçekleştirerek durum tespiti yapmışlardır. Örnekler arasında gerek bileşim gerekse asitlik değerlerinin oldukça değişken ve maya ve küf sayilarının da oldukça yüksek olduğunu belirlemişlerdir. Ayrıca, araştırmacılar tarafindan izole edilen küflerin \%93.5'i Penicillium cinslerine ait türler olarak tespit edilmiştir. Diğer adlarla üretilen küp peynirleri üzerine de sinırlı sayıda çalışmaya rastlanmıştır. Kaptan (2016), evlerde yapilan ve semt pazarlarında satılan farkli illerden (Ankara, Kayseri, Kırşehir, Nevşehir, Niğde, Sivas ve Yozgat) topladığ1 279 küp peyniri örneğinde Listeria türlerinin varlığını incelemiş ve bazı örneklerde Listeria monocytogenes tespit etmiştir. Ankara, Yozgat ve Nevşehir illerinden alınan toprak ambalajlarda olgunlaştırılan küp peynirlerinden 60 örneğin \%41'inde $0.016 \mu \mathrm{g} / \mathrm{kg}$ ile $0.136 \mu \mathrm{g} / \mathrm{kg}$ arasinda Aflatoksin M1 tespit edilmiş ve bu örneklerin 5 tanesinin uluslararası izin verilen değeri aşttğı bildirilmiştir (Koluaçık, 2014). Coşkun vd. (2002), yağın ve haşlama işleminin Yozgat küp (çanak) peynirinin nitelikleri üzerine etkilerini incelemişler ve tam yağlı sütten pihtısı haşlanarak yapılan peynirin duyusal olarak en iyi sonucu verdiğini bildirmişlerdir. Güler (1999), çiğ ve pastörize inek ve keçi sütlerinden üretilen Hatay'n yöresel Carra peynirlerini, sirlı 
testilerde ve polietilen kaplarda toprağa gömerek ya da buzdolabinda olgunlaştırmıştır. Carra peyniri ambalaj1 olarak kullanılan sırlı testilerin yerine şeffaf polietilen kapların da başarı ile kullanılabileceği, 3 ay süre ile toprağa gömme yerine buzdolabinda olgunlaştırmanın duyusal açıdan oldukça olumlu sonuç verdiği bildirilmiştir. En kaliteli Carra peynirinin pastörize keçi sütünden üretilen ve pet kavanozda buzdolabında olgunlaştırılan peynir olduğu bildirilmiştir.

Yöre halkı tarafindan buzdolabinda muhafaza edilen Sivas küp peynirlerinin daha uzun süre dayandığı ve peynirlerde acılaşmanın daha az olduğu savunulmaktadır. Buna karşın, toprakta olgunlaştırılarak tüketilen küp peynirinin ise daha çok beğenildiği dillendirilmektedir. Sivas küp peynirinde bu iki olgunlaştırma koşulu arasındaki fark1 ve nedenlerini ortaya koyacak literatürde herhangi bir çalsşmaya rastlanmamıştır. Dolayısıyla, bu çalışmada, mahalli peynir çeşitlerimizden olan Sivas küp peynirinin buzdolabında ve toprağa gömülerek iki farklı şekilde olgunlaştırılmasının; peynirin bileşimi, lipoliz ve proteoliz düzeyi, duyusal özellikleri ile maya ve küf düzeyleri üzerine etkisinin araştırılması amaçlanmıştır. Ayrıca, çalışmada peynir üretiminin tamamen yörede ve varolan koşullarda gerçekleştirilmesi de, gerçek bir durum tespitinin yapılmasına katkı sağlayacaktır.

\section{MATERYAL VE YÖNTEM}

\section{Materyal}

Peynir üretiminde yağ1 azaltılmış inek sütü ve peynirlerin ambalajlanmasinda 1'er kilogramlık plastik kavanozlar kullanılmışır.

\section{YÖNTEM}

\section{Sivas küp peyniri üretimi}

Peynir örnekleri, küp peyniri üretiminde Sivas'ın Karşıyaka mahallesinde bir çiftlikte yaygın olarak kullanılan geleneksel yöntemle üretilmiştir. Üretim 3 tekerrürlü olarak gerçekleştirilmiş ve her üretimde 90 litre yağı azaltılmış inek sütü kullanılmıştır. Çiğ süt, bir tülbent yardımıyla süzülmüştür. $32^{\circ} \mathrm{C}^{\prime}$ ye 1 sittlan süte $17 \mathrm{~mL}$ peynir mayası ilave edilmiş (maya kuvveti: $1 / 8500$, Süper marka) ve yaklaşık 45 dakika boyunca pıhtılaşmaya bırakılmıştır. Daha sonra pıhtı bir oklava yardımıyla 4'e kesilmiş ve peynir suyunun kolayca ayrılması için 15 dakika süreyle 1sıtma işlemi (pıhtı sıcaklı̆̆ı: $48-50^{\circ} \mathrm{C}$ ) gerçekleştirilmiştir (Şekil 1a ve 1b). Arkasından bir kâse yardımıyla peynir suyunu uzaklaştırmak için keselere aktarılmıştır (Şekil 1c). Yaklaşık 20 dakika sonra taşlarla baskılanarak karanlık bir odada 2 gün bekletilmiştir (Şekil 1d). Sonrasında peynirler kalıplar halinde kesilerek tuzlanmış ve ardından 1'er kilogramlık plastik kavanozlara basılmıştır (Şekil 1e ve 1f). Boşluklar, peynir kırıkları ile sıkıca doldurulmuştur. Kavanozun ağız kısmına bir miktar tuz eklenmiş ve kapakları kapatılmıştır. 90 L sütten $8.5 \mathrm{~kg}$ peynir elde edilmiştir. Ertesi gün buzdolabında olgunlaştırılacak örnekler için kavanozların kapaklarına bıçak yardımıyla delik açılıp ters çevrilerek, buzdolabına $\left(6-10^{\circ} \mathrm{C}\right)$ yerleştirilmiş; toprakta olgunlaştırllacaklar için ise kavanozların ağzı bezle bağlanıp ters çevrilerek, serin bir ortamda toprağa tamamiyla gömülmüş̧ür. Bütün örnekler 90 gün boyunca olgunlaşmaya bırakilmış ve hemen üretim sonrası, 15., 30., 60. ve 90. günlerde her bir analiz günü yeni bir kavanoz açlarak peynirler analize tabi tutulmuştur.

\section{Peynir örneklerinin analize hazırlanması}

Fiziksel, kimyasal, duyusal ve mikrobiyolojik analizler için peynir örnekleri ISO 707/IDF 50 (2008)'ye göre alınmıştır. Önce aseptik teknikle mikrobiyolojik analizler için örnek alınmıştır. Daha sonra kimyasal analizler ve duyusal değerlendirmeler için, aynı peynir kavanozlarından bir kaşık yardımıyla peynirler çıkarılmış ve yaklaşık $200 \mathrm{~mL}$ hacmindeki temiz kapaklı cam kavanozlara aktarılmıştır. Peynir kalıplarının geri kalan kısımları ise; gerektiğinde kullanılmak üzere $-18^{\circ} \mathrm{C}$ 'de saklanmıştır.

\section{Analiz yöntemleri}

Bilesim ve asitlik analizleri

Peynir üretiminde kullanılan sütün kurumadde oran1 gravimetrik yöntemle (AOAC., 2007a), protein oranı Kjeldahl yöntemiyle elde edilen toplam azot oranının 6.38 faktörü ile çarpılmasıyla (AOAC, 2007b), sütün yağ oranı Gerber yöntemiyle (IDF, 1981) belirlenmiştir. Peynirlerin ise, kurumadde oranı gravimetrik yöntemle (IDF, 1982), yağ oranı Van-Gulik yöntemiyle (TSE, 
1978) ve tuz oranı Mohr yöntemiyle (IDF, 1988) belirlenmiştir. Süt ve peynirin asitliği, \% laktik asit cinsinden titrimetrik yöntemle (AOAC, 2007c, d,
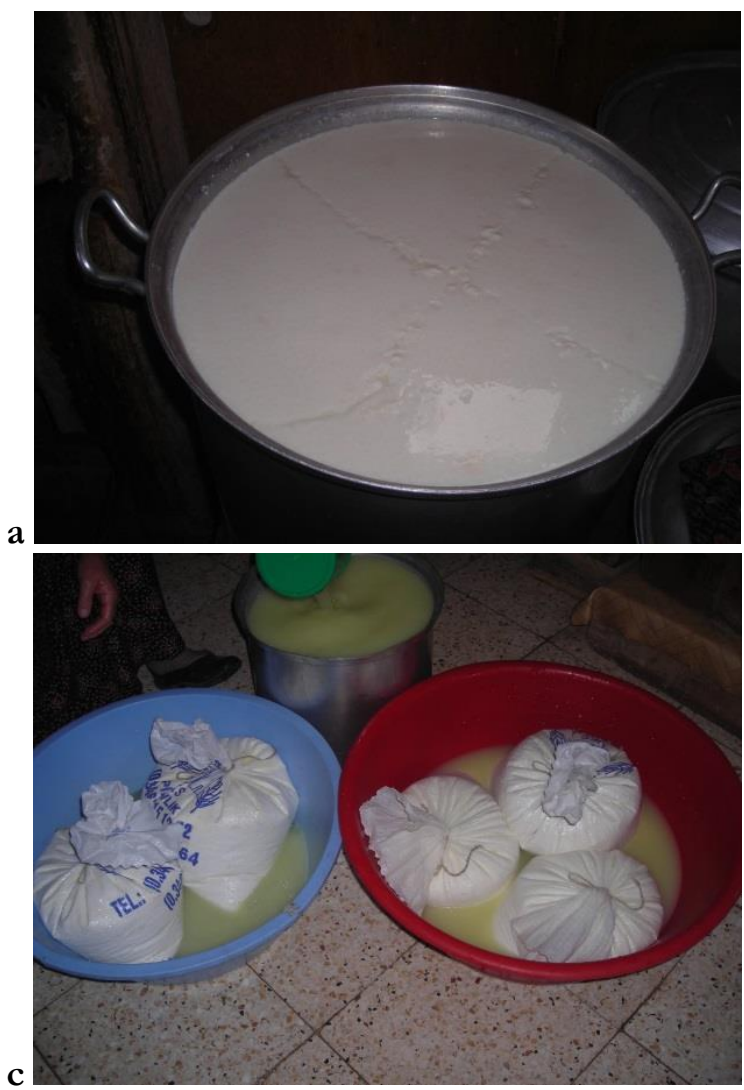

b

sırasıyla), $\mathrm{pH}$ değerleri ise $\mathrm{pH}$ metre ile (WTW marka Inlab Level-1 model) saptanmıştır.
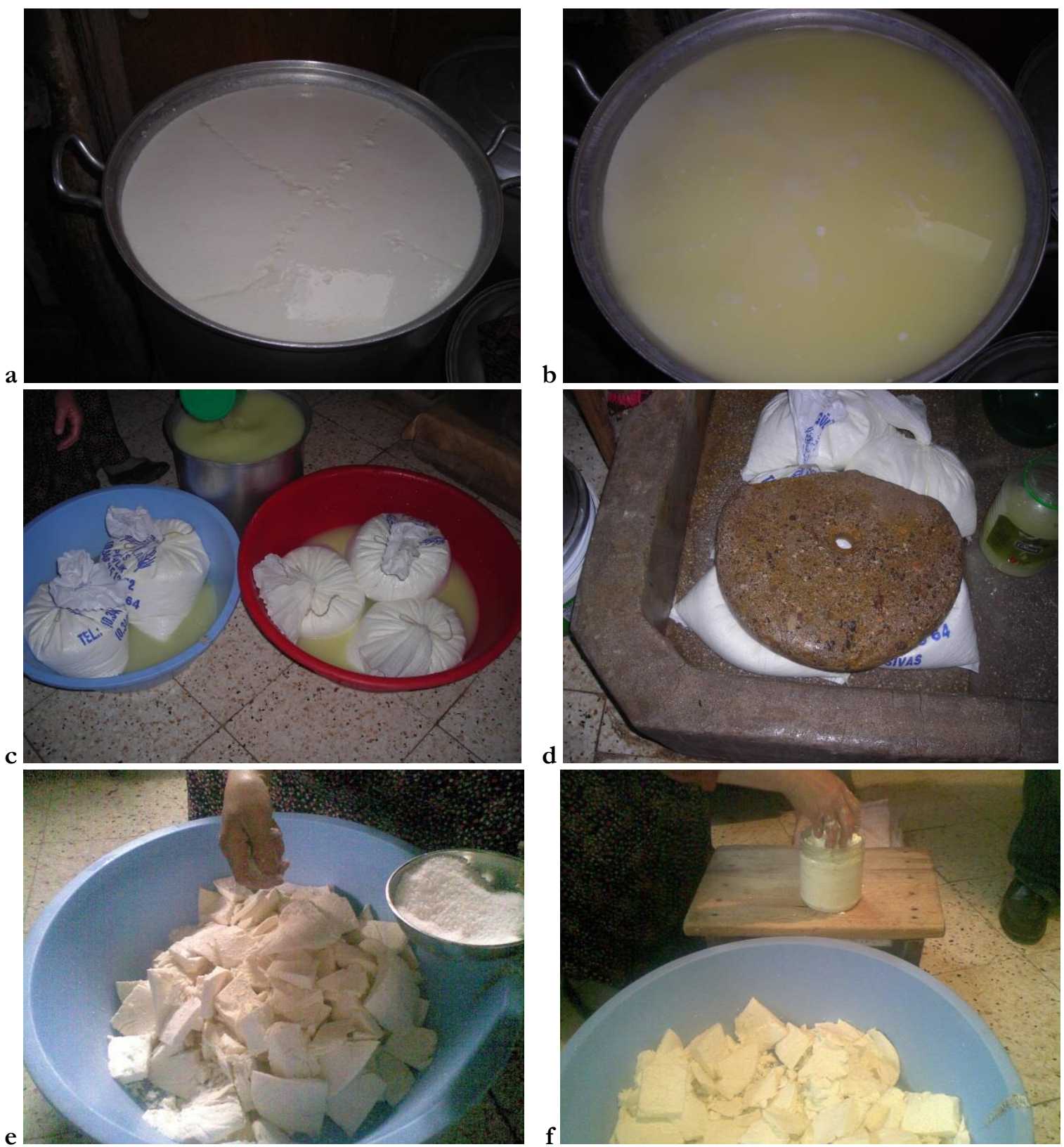

Şekil 1. Geleneksel yöntemle deneme peynirlerinin üretimi (a: pıhtının oklava ile kesilmesi, b: pıhtının 1sıtılması, c: pıhtının keselere aktarılması, d: baskılanması, e: kesilmiş telemenin tuzlanması, f: kavanozlara basilmasi)

Figure 1. Traditional production of experimental cheeses (a: cuttig the curd into four pieces, $b$ : scalding of curd, c: moving the curd into pouch, d: pressing, e: salting, f: stuffing the cheese into jar) 
Serbest yağ asitliği anali

Peynir örneklerinde yağ ekstraksiyonu, Nunez vd. (1986) ile Öztürk (1993) tarafindan belirtilen şekilde bazı küçük modifikasyonlar yapılarak gerçekleştirilmiştir. Rendelenmiş peynir örneğinden $10 \mathrm{~g}$ tartılmış ve üzerine $6 \mathrm{~g}$ susuz $\mathrm{NaSO}_{4}$ ilave edilmiş ve bir havan içerisinde ezilmiştir. Daha sonra karışım şilifli-kapaklı erlene alınmış ve $60 \mathrm{~mL}$ dietileter ilave edilerek 1 saat bekletilmiştir. $\mathrm{Bu}$ süre içerisinde karışım her 15 dakikada 1 dakika süre ile karıştırılmıştır. Sıv1 kısım süzülmüştür (S\&S, 589, beyaz bant). Bu işlem, $20 \mathrm{~mL}$ dietileter ilave edilerek $3 \mathrm{kez}$ tekrarlanmış ve süzüntü şilifli erlende toplanmıştır. Erlende toplanan dietileter-yağ karışımından, dietileter $50^{\circ} \mathrm{C}$ 'de bir dönerli vakumlu evaporator (Buchi Rotavapor-RE, $\mathrm{CH}-$ 9230 Flawil, İsveç) yardımı ile vakum altında uzaklaştırılmıştır. Elde edilen yağ bir erlen içerisine tartıldıktan sonra $10 \mathrm{~mL}$ dietileter:etil alkol karışımı (1:1) ilave edilmiş ve $0.05 \mathrm{~N}$ etil alkolde hazırlanmış $\mathrm{KOH}$ ile \%1'lik fenolftalein indikatörlügünde titre edilmiştir. Sonuç, \% oleik asit cinsinden ifade edilmiştir.

\section{Olgunlașa düzeylerinin belirlenmesi}

Suda çözünür azot (SÇA) ve \%12 trikloroasetik asitte çözünür azot (TCA-ÇA) oranı Bütikofer vd. (1993) ve Ardö (1999)'ye göre, \%5 fosfotungusitik asitte çözünür azot (PTA-ÇA) oranı, Jarrett vd. (1982)'ye göre belirlenmiştir. 10 gram peynir örneği, $50 \mathrm{~mL} 40^{\circ} \mathrm{C}^{\prime}$ deki saf su ile Ultra Turrax'da maksimum hızda homojen hale getirilmiş ve homojenat $40^{\circ} \mathrm{C}$ 'de 1 saat su banyosunda bekletilmiştir. Daha sonra yöntemde belirtilen 3000 g'de 30 dakika yerine $4^{\circ} \mathrm{C}$ ve 4000 $\mathrm{rpm} /$ dak.'da 45 dakika santrifüj işlemi uygulanmıştır (Koca, 2002). Elde edilen süspansiyon cam pamuğundan süzülmüş ve süzüntünün $15 \mathrm{~mL}$ 'si Kjeldahl yöntemi ile azot tayininde kullanılmıştır. Sonuç, suda çözünür azot (\%) (SÇA) olarak hesaplanmıştır. Süzüntüden 25 $\mathrm{mL}$ alınmış ve üzerine $25 \mathrm{~mL}$ trikloroasetik asit (TCA) çözeltisi $(240 \mathrm{~g} / \mathrm{L})$ ilave edilmiştir. Oda sıcaklığında 2 saat bekletilmiş ve filtre kâğıdından (Whatman No. 41) süzülmüştür. Süzüntünün tümü Kjeldahl metodu ile azot tayininde kullanılmıştır. Sonuç, TCA'da çözünür azot (\%) (TCA-ÇA) olarak verilmiştir. Suda çözünen azot analizinde elde edilen süzüntüden $5 \mathrm{~mL}$ alınmış ve üzerine $3.5 \mathrm{~mL} \mathrm{H} \mathrm{SO}_{4}$ çözeltisi $(3.95 \mathrm{M})$ ile 1.5 $\mathrm{mL}$ fosfotungusitik asit (PTA) çözeltisinden $(\% 33.3)$ ilave edilmiştir. Karışım $+4^{\circ} \mathrm{C}$ 'de 1 gece bekletildikten sonra filtre kâğıdından (Whatman No. 42) süzülmüştür. Elde edilen süzüntünün azot içeriği Kjeldal metodu ile saptanmıştır. Sonuç, fosfotungusitik asitte çözünür azot (\%) (PTA-ÇA) olarak hesaplanmıştır. SÇA, TCA-ÇA, PTA-ÇA değerleri, toplam azot değerlerine oranlanarak, peynir örneklerinin olgunlaşma dereceleri $\%$ olarak tespit edilmiştir.

Maya ve küf saym

Aseptik koşullarda alınan $10 \mathrm{~g}$ peynir örneği, 90 $\mathrm{mL}$ Maximum Recovery Diluent (Merck) ile homojen hale getirilmiş, sonra $10^{-7}$ ye kadar seri dilüsyonlar hazırlanmıştır. Dichloran Rose Bengal Chloramphenicol Agar (Merck) bulunan petrilere yayma plak yöntemiyle ekim yapılmıştır. Petriler $25 \pm 1{ }^{\circ} \mathrm{C}$ 'de 5 gün boyunca inkübasyona bırakilmış ve 10-150 koloni arasındaki petriler hesaplamaya alınmıştır. Sonuçlar log kob/g olarak verilmiştir (FDA, 2001).

\section{Duyusal değerlendirme}

Sivas küp peynirinin duyusal değerlendirmesi puanlama yöntemiyle yapılmıştır. Bu amaçla, öncelikle peynirin duyusal kalite kriterleri ve bu kalite kriterlerine karşılık gelen puanlar farklı üreticilerden temin edilen küp peynirleri kullanılarak belirlenmiştir. Ayrıca, panelistlere söz konusu örnekler ile eğitim verilmiştir. Duyusal değerlendirme, Sivas küp peynirini taniyan 9 panelist ile gerçekleştirilmiştir. Panelistlerden belirlenen puanlama kriterlerine göre 1-5 arasında peynir örneklerini görünüş, doku, lezzet ve tüm izlenim açısından değerlendirmeleri ve ayrıca puan düşüşlerine neden olan kusurları işaretlemeleri istenmiştir.

\section{İstatistiksel analizler}

Analiz sonuçlarının varyans analizi ile değerlendirilmesinde ise, iki faktör (olgunlaşma koşulu ve depolama süresi) üzerinden iki yönlü varyans analizi uygulanmış ve önemli çıkan faktörlerin ortalamaları Duncan testi ile karşılaştırılmıştır. Bu amaçla, SPSS (sürüm 16.0) ticari istatistik paketi kullanılmıştır. 


\section{ARAŞTIRMA SONUÇLARI VE TARTIŞMA}

Peynir üretiminde kullanılan çiğ inek sütünün kurumadde oranı $\% 11.67 \pm 0.23$, yağ oranı $\% 2.17 \pm 0.15$, protein oranı $\% 3.01 \pm 0.06$ olarak tespit edilmiştir. Sütlerin $\mathrm{pH}$ değerleri $6.70 \pm 0.08$, titrasyon asitliği değerleri ise laktik asit cinsinden $\% 0.21 \pm 0.01$ olarak bulunmuştur.

Peynir üretimi boyunca süt ve pihtının $\mathrm{pH}$ 'sı takip edilmiştir. Maya ilavesi sırasında sütün $\mathrm{pH}$ değeri 6.62, pihtılaşma işlemi sonunda 5.98, pihtının 1sitılması sonrasinda 5.82 olarak tespit edilmiş, peynirin kavanoza yerleştirilmesi aşamasında ise pH değeri 4.91'e düşmüştür. Toprağa gömülen ve buzdolabinda depolanan peynirler 90 gün boyunca üretim sonras1, 15., 30., 60. ve 90. günlerde fizikokimyasal ve mikrobiyolojik analizlere tabi tutulmuştur. Duyusal analiz ise, çiğ süt kullanılması sebebiyle olgunlaşma süresi sonunda gerçekleştirilmiştir.

\section{Peynirin bileşimi ve asitliği üzerine etkisi}

Hem toprakta hem de buzdolabinda olgunlaştırılan peynirlerin $\mathrm{pH}$ değerlerinde olgunlaşma süresince artış saptanmıştır (Çizelge 1). Ancak, toprakta olgunlaşan peynirlerin $\mathrm{pH}$ değerleri, buzdolabında olgunlaşan peynirlere kıyasla olgunlaşmanın 30. gününden itibaren daha yüksek seyretmiştir $(P<0.01)$. Farkye ve Fox (1990), üretim sırasında ve olgunlaşmanın ilk aşamalarında pıhtıda kalan laktozun parçalanması sonucu laktik asit oluşumu nedeniyle peynir çeşidine bağlı olarak pH'nın düştüğünü, olgunlaşma sırasında ise laktik asitin başka ürünlere parçalanması ve/veya alkali azotlu bileşiklerin oluşumuyla peynir pH'sının arttı̆̆ını bildirmektedir. Bu artış özellikle küflü peynirlerde daha belirgin olmaktadır. Araştırmalarda TrieuCout ve Gripon (1982) ile Karahadian ve Lindsay (1987), Camembert peynirlerinin pH'sinin 4.8'lerden 7.5'lere kadar, Godinho ve Fox (1982), mavi küflü peynirlerde 4.8'lerden 7'lere kadar arttı̆̆ını saptamışlardır. Çalışmada da Sivas küp peynirlerinin $\mathrm{pH}$ değerlerinin artış1, hatta bu artışın toprakta olgunlaştırılanlarda daha fazla oluşu, peynirlerin küf oranının yüksek olması ile açıklanabilir. Buna karşın, peynirlerin olgunlaşma şekillerinin (toprak, buzdolabi), peynirlerdeki titrasyon asitliği değerleri üzerine etkisi istatistiksel olarak önemli bulunmamıştır $(P>0.05)$. Bu değerler her iki grup için de ilk 15 gün içinde azalmış, daha sonra artış göstermiştir $(P<0.01)$. $\mathrm{Bu}$ durum, olgunlaşma boyunca laktik asit oluşumu ve laktik asidin küfler tarafindan başka ürünlere parçalanması arasında denge ile ilişkilendirilebilinir.

İlk 15 gün içinde her iki grupta da kurumadde değerlerinde önemli bir artış saptanmıştır. Bu artış, toprakta olgunlaştırılan peynirde daha belirgindir $(P<0.05)$. Bu durum, peynir suyunun süzülmeye devam etmesiyle açılanabilir. Nitekim üretim sonrasında kavanozların kapakları delinmiş ve ters çevrilerek olgunlaşmaya bırakılmıştır. Daha sonraki günlerde ise, kurumadde değerlerinde önemli bir değişim belirlenmemiştir. Olgunlaştırma süresince protein ve yağ oranlarında, her iki grup için de kurumadde değerlerine paralel olarak doğrusal bir artış saptanmıştır. Toprakta olgunlaştırılan peynirlerin kurumaddelerinin yüksek olması sebebiyle, yağ ve protein içerikleri de daha yüksek tespit edilmiştir $(P<0.05)$. Yağ ve protein oranlarındaki eğilimin tam tersi şekilde, peynir örneklerinin olgunlaşma süresince tuz içeriklerinde azalma tespit edilmiştir. $\mathrm{Bu}$ azalma ise, olgunlaşma süresince peynirden ayrilan suyla birlikte bir miktar tuzun da uzaklaşmasıyla açıklanabilir. Toprakta olgunlaştırılan peynirlerde kurumadde oranlarında 15. günde daha belirgin bir artış nedeniyle, su kaybının daha hizlı olduğunu söylemek mümkündür. Nitekim bu peynirlerin doldurulduğu kavanozlar kapaksız bir şekilde ağız kısımları kumaş parçalarıyla bağlanarak toprağa gömülmüştür. Bu durum, toprakta olgunlaştırılan peynirlerde bu tuz oraninda azalmanin, olgunlaşmanın daha erken (15.gün) safhalarında gerçekleşmesine neden olmuştur. 60. günden itibaren her iki grup için yakın tuz değerleri elde edilmiştir.

\section{Peynirin maya-küf sayısı üzerine etkisi}

Sivas küp peyniri örneklerinin maya ve küf sayıs1 üretim sonrasında yüksek seviyede $(3.81 \pm 0.19 \mathrm{log}$ $\mathrm{kob} / \mathrm{g}$ ) tespit edilmiştir. Bu durum, tamamen geleneksel olarak yapılan üretim sirasinda her ne kadar temizliğe dikkat edilse de, önemli düzeyde bir küf bulaşmasının söz konusu olduğunu 
göstermektedir. Özellikle, Sivas küp peyniri üretim yönteminde bahsedildiği gibi, üretilen taze peynirler tuzlanıp kavanozlara yerleştirilmeden önce 2 gün taş kalıplarla baskılanmıştır. Bu aşama, küf bulaşması için oldukça uygun bir ortam yaratmaktadır. Her iki olgunlaşma şeklinde de olgunlaşma süresince maya ve küf sayısında artış saptanmıştır. $\mathrm{Bu}$ artış, toprakta olgunlaştırilan peynirde ilk 15 günde daha belirgin olmuştur.
Toprak, küflerin bulaşma kaynaklarından birisidir. $\mathrm{Bu}$ nedenle toprakta olgunlaştrrilan grupta özellikle başlangiçta görülen bu yükseklik, topraktan peynire küf bulaşması ile açıklanabilir. Pekel ve Korukoğlu (2009)'da, Sivas yöresinden sağladıkları 25 adet küp peynirinde oldukça yüksek maya ve küf sayıları (ortalama $7.57 \mathrm{log}$ $\mathrm{kob} / \mathrm{g}$ ) tespit etmişlerdir.

Çizelge 1. Sivas küp peynirlerinin olgunlaşma süresince bileşim ve asitlik değerlerindeki değişimler (ortalama \pm standart sapma)

Table 1. The changes in composition and acidity of Sivas këp cheese during ripening period (mean土standard deviation)

\begin{tabular}{|c|c|c|c|c|c|c|}
\hline & \multicolumn{5}{|c|}{ Olgunlaşma süresi (Gün) / Ripening period (Day) } \\
\hline & & 0 & 15 & 30 & 60 & 90 \\
\hline \multirow{2}{*}{$\begin{array}{l}\text { Kurumadde } \\
(\%)\end{array}$} & $\mathrm{T}$ & $46,80 \pm 0,80^{a}$ & $55,45 \pm 0,85^{\mathrm{bx}}$ & $55,44 \pm 0,92^{\mathrm{bx}}$ & $55,11 \pm 0,87 \mathrm{bx}$ & $54,88 \pm 0,74^{\text {bx }}$ \\
\hline & B & $46,80 \pm 0,80^{a}$ & $51,41 \pm 1,14^{\text {by }}$ & $52,70 \pm 1,27$ by & $52,63 \pm 1,33^{\mathrm{bx}}$ & $52,29 \pm 1,58^{\mathrm{bx}}$ \\
\hline \multirow{2}{*}{ Yağ $(\%)$} & $\mathrm{T}$ & $24,33 \pm 1,53^{\mathrm{ax}}$ & $25,33 \pm 1,53 \mathrm{abx}$ & $26,52 \pm 1,30^{\mathrm{abx}}$ & $27,67 \pm 1,15 \mathrm{bcx}$ & $29,35 \pm 1,05^{\mathrm{cx}}$ \\
\hline & $B$ & $24,33 \pm 1,53^{\mathrm{abx}}$ & $23,30 \pm 1,49$ ax & $24,26 \pm 1,51$ aby & $25,46 \pm 1,56^{\text {aby }}$ & $26,83 \pm 1,26^{\text {by }}$ \\
\hline \multirow{2}{*}{ Protein (\%) } & $\mathrm{T}$ & $19,02 \pm 0,13^{\mathrm{a}}$ & $20,05 \pm 0,45^{\mathrm{cx}}$ & $19,87 \pm 0,40^{\mathrm{bcx}}$ & $19,42 \pm 0,39 \mathrm{abcx}$ & $19,22 \pm 0,29 \mathrm{abx}$ \\
\hline & B & $19,02 \pm 0,13 \mathrm{ab}$ & $18,75 \pm 0,38$ ay & $19,20 \pm 0,26^{\mathrm{bx}}$ & $19,71 \pm 0,10^{\mathrm{cx}}$ & $19,77 \pm 0,06$ су \\
\hline \multirow{2}{*}{ Tuz (\%) } & $\mathrm{T}$ & $6,68 \pm 0,10^{\mathrm{d}}$ & $4,97 \pm 0,12^{\mathrm{cx}}$ & $4,58 \pm 0,23^{b x}$ & $4,38 \pm 0,19 \mathrm{abx}$ & $4,27 \pm 0,11_{\text {ax }}$ \\
\hline & B & $6,68 \pm 0,10^{\mathrm{d}}$ & $6,18 \pm 0,08$ су & $5,64 \pm 0,27$ by & $4,20 \pm 0,09$ ax & $4,12 \pm 0,07 \mathrm{ax}$ \\
\hline \multirow{2}{*}{$\begin{array}{l}\text { KM'de yağ } \\
(\%)\end{array}$} & $\mathrm{T}$ & $51,97 \pm 2,4 c$ & $45,67 \pm 2,14 \mathrm{ax}$ & $47,82 \pm 1,54 \mathrm{abx}$ & $50,19 \pm 1,32^{\mathrm{bcx}}$ & $53,47 \pm 1,40^{\mathrm{cx}}$ \\
\hline & B & $51,97 \pm 2,4 \mathrm{~b}$ & $45,31 \pm 2,24$ ax & $46,06 \pm 3,34$ abx & $48,43 \pm 3,90^{\mathrm{abx}}$ & $51,39 \pm 3,87 \mathrm{abx}$ \\
\hline \multirow{2}{*}{$\begin{array}{l}\text { KM'de } \\
\text { protein (\%) }\end{array}$} & $\mathrm{T}$ & $40,65 \pm 0,82^{\mathrm{b}}$ & $36,16 \pm 0,73^{\mathrm{ax}}$ & $35,84 \pm 0,97 \mathrm{ax}$ & $35,25 \pm 1,09 \mathrm{ax}$ & $35,02 \pm 0,91^{\mathrm{ax}}$ \\
\hline & B & $40,65 \pm 0,82^{\mathrm{b}}$ & $36,48 \pm 0,59$ ax & $36,45 \pm 1,30^{\text {ax }}$ & $37,47 \pm 0,92^{\mathrm{ax}}$ & $37,82 \pm 1,09$ ay \\
\hline \multirow{2}{*}{$\begin{array}{l}\text { KM'de tuz } \\
(\%)\end{array}$} & $\mathrm{T}$ & $14,27 \pm 0,38^{\mathrm{d}}$ & $8,97 \pm 0,10^{c x}$ & $8,25 \pm 0,27 \mathrm{bx}$ & $7,95 \pm 0,23$ abx & $7,79 \pm 0,11^{\text {ax }}$ \\
\hline & B & $14,27 \pm 0,38^{\mathrm{d}}$ & $12,02 \pm 0,14 \mathrm{cy}$ & $10,72 \pm 0,67$ by & $7,99 \pm 0,34$ ax & $7,89 \pm 0,35^{\text {ax }}$ \\
\hline \multirow{2}{*}{$\mathrm{pH}$} & $\mathrm{T}$ & $4,82 \pm 0,12^{\mathrm{a}}$ & $4,91 \pm 0,02^{\mathrm{ax}}$ & $5,11 \pm 0,01^{\mathrm{bx}}$ & $5,24 \pm 0,0^{\text {cx }}$ & $5,31 \pm 0,02^{\mathrm{cx}}$ \\
\hline & B & $4,82 \pm 0,12^{\mathrm{a}}$ & $4,90 \pm 0,01 \mathrm{abx}$ & $4,99 \pm 0,03$ by & $5,18 \pm 0,0^{\mathrm{cx}}$ & $5,18 \pm 0,03$ су \\
\hline \multirow{2}{*}{$\begin{array}{l}\text { TA } \\
(\% \mathrm{LA})\end{array}$} & $\mathrm{T}$ & $1,54 \pm 0,07 \mathrm{c}$ & $0,95 \pm 0,04^{a x}$ & $1,20 \pm 0,06^{\mathrm{bx}}$ & $1,57 \pm 0,06^{\mathrm{cx}}$ & $1,67 \pm 0,04 \mathrm{dx}$ \\
\hline & B & $1,54 \pm 0,07 \mathrm{c}$ & $1,06 \pm 0,12^{\text {ax }}$ & $1,26 \pm 0,06^{\mathrm{bx}}$ & $1,49 \pm 0,07 \mathrm{cx}$ & $1,61 \pm 0,07 \mathrm{cx}$ \\
\hline
\end{tabular}

$\mathrm{T}$ : Toprakta olgunlaştırlan peynir (the cheese ripened being burried in soil)

B: Buzdolabın koşullarında olgunlaştırılan peynir (the cheese ripened under refrigerated conditions)

a-c: Aynı satırda farklı harflerle gösterilen ortalama değerler birbirinden farklıdır $(\mathrm{P}<0.05)$.

a-c: The mean values shown in different letters on the same line are different $(P<0.05)$

$\mathrm{x}-\mathrm{y}$ : Aynı sütunda farklı harflerle gösterilen ortalama değerler birbirinden farklıdır $(P<0.05)$

$x-y$ : The mean values shown in different letters in the same column are different $(P<0.05)$

\section{Peynirin lipolizi ve proteolizi üzerine etkisi}

Her iki grup peynirde de serbest yağ asitliği değerleri olgunlaşmanın ilk 15 gününde hızla $\operatorname{artmış~}(P<0.01$, Şekil 3), sonrasında ise çok fazla olmamakla birlikte peynirlerin serbest yağ asitliği değerlerinde düşüşler meydana gelmiştir $(P$ $>0.05)$. Benzer bir durum, Dervişoğlu ve Yazıcı (2001) tarafindan Külek peynirinde de bildirilmiştir. Araştırmacılar lipolitik aktiviteye sahip mikroorganizmaların olgunlaşma işleminin ilk bir ayında hızla artı̆̆ını, fakat daha sonra pek fazla değişmediğini belirtmișlerdir. Olgunlașma süresince serbest yağ asitleri metil ketonlara dönüşebilmekte veya bazı yağ asitleri de küfler tarafindan enerji kaynağ1 olarak kullanılabilmektedir. Nitekim Sivas küp peyniri örneklerinde de küf sayıları oldukça yüksektir. 


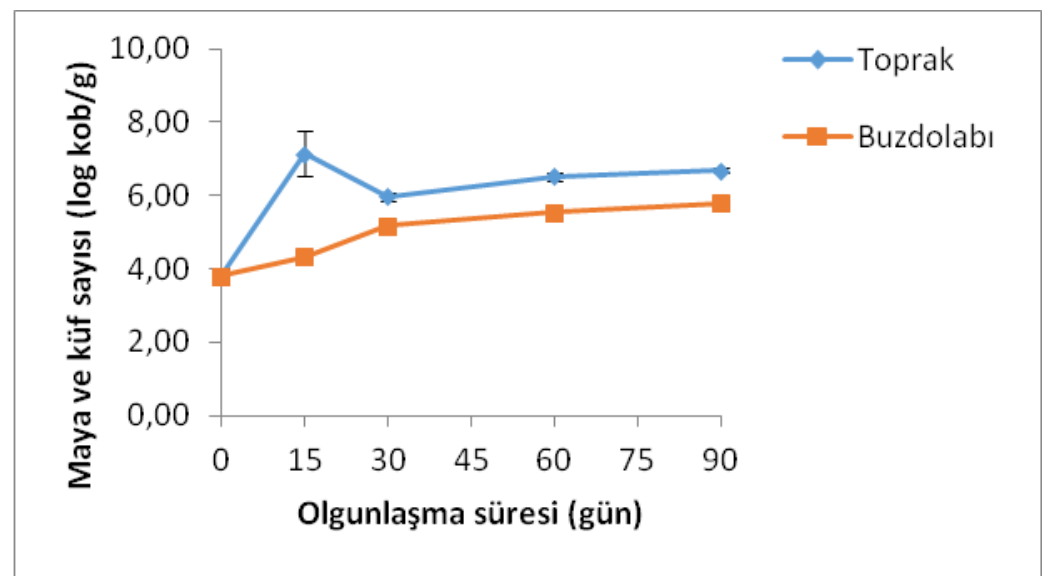

Şekil 2. Sivas küp peynirlerinin olgunlaşma süresince küf ve maya saylları Figure 2. Mold and yeast counts of Sivas küp cheeses during ripening

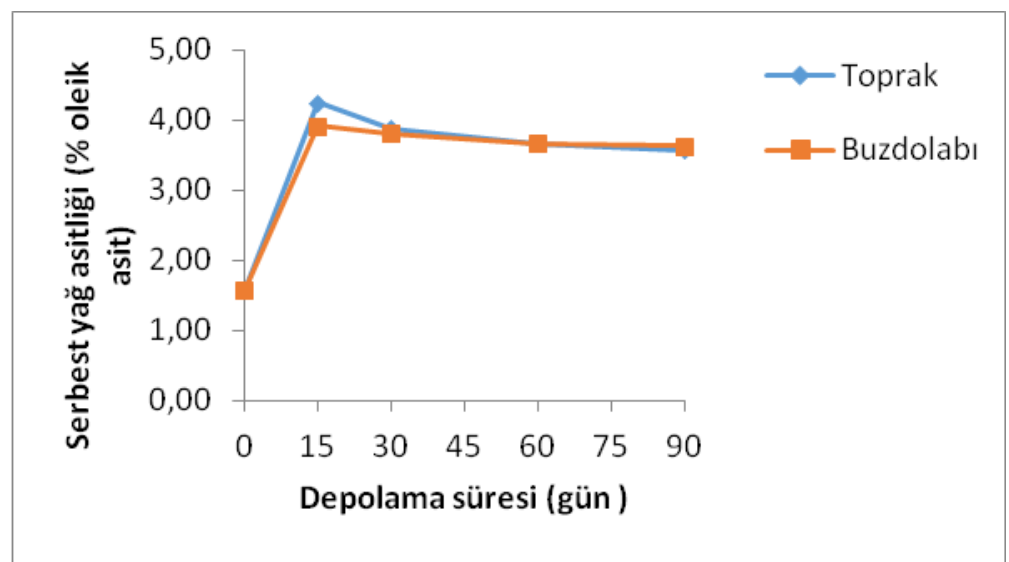

Şekil 3. Sivas küp peynirlerinin olgunlaşma süresince serbest yağ asitliği değerleri Figure 3. Free fatty acid values of Sivas küp cheeses during ripening

Toprakta olgunlaşan peynirlerin SÇA, TCA-ÇA ve PTA-ÇA değerleri, olgunlaşma süresince buzdolabında olgunlaşan peynirlerin değerlerine kıyasla daha yüksek seyretmiştir $(P<0.05$, Çizelge $2)$. Her iki olgunlaştırma şeklinde de bu değerler olgunlaşma ilerledikçe artı̧̧ göstermiştir $(P<0.01)$. Peynirde tuz lezzet ve kaiteye etki ederken, peynirin korunmasinda da rol oynar. Tuz gidaların sıv1 fazındaki osmatik basınc1 artırır, böylece bakteri hücrelerinin dehidrasyonuna sebep olarak ya ölmelerine ya da gelişimlerinin engellenmesine yol açar. Dolayısıyla peynirdeki tıuz oranı, mikrobiyolojik ve enzimatik aktiviteleri etkileyerek, glikoliz, lipoliz ve proteoliz düzeylerini etkiler (Guinee, 2007). Toprakta olgunlaştırılan peynirlerin tuz oranı, olgunlaşmanın erken dönemlerinde buzdolabında olgunlaştırılanlara kıyasla daha düşük seyretmiştir. $\mathrm{Bu}$ durum, toprakta olgunlaştırılan peynirlerde proteoliz oranının yüksek olmasında tuz oranının da etkin bir faktör olduğunu düşündürmüsstür.

SÇA bazında olgunlaşma düzeyi her iki grupta da ilk 15 gün içinde önemli bir artışla neredeyse iki katına çıkmış ve 30. ve 60. günlerde bu artış yavaşlamışır. TCA-ÇA bazında olgunlaşma düzeyi ise, 15. ve 30. günlerde önemli bir artıs göstermiş ve daha sonra neredeyse stabil kalmıştır. PTA-ÇA bazında olgunlaşma düzeyi ise her ne kadar düzenli olarak olgunlaşma süresince artsa da, bu artış 60. ve 90. günlerde oldukça belirgin düzeye gelmiştir. $\mathrm{Bu}$ üç farklı olgunlaşma kriterinin gün bazında bu değişimleri, ekstraksiyonda temsil ettikleri azot fraksiyonları 
ve bunların birbirine dönüşümü ile açıklanabilir. Su ile ekstraksiyonda kazein dişındaki protein, tüm peptitler, aminoasitler, aminler, üre ve amonyak gibi bileşikler alınırken, TCA ile ekstraksiyonda ise orta ve küçük molekül ağırlıklı peptitler ile aminoasitler, aminler, üre ve amonyak gibi bileşikler analiz edilebilmektedir (Hayaloğlu vd., 2011). Nitekim, analizde TCA-ÇA tayininde suda çözünür fraksiyon kullanılmış ve büyük molekül ağıllıklı peptitler çöktürülmüştür. PTA ile ekstraksiyonda ise sadece çok düşük molekül ağırlıklı peptitler ile aminoasitler elde edilmektedir
(Hayaloğlu vd, 2011). Olgunlaşma düzeyi ilerledikçe, küçük molekül ağırlıklıklı peptitlere parçalanmanın ve aminoasit oluşumunun artışı dikkate alındığında PTA-ÇA bazında olgunlaşma düzeyinin ileri olgunlaşma günlerinde artışı anlamlıdır. SÇA bazında olgunlaşmayı değerlendirdiğimizde ise, büyük moleküllü peptit oluşumunun olgunlaşma başında belirgin olması ve daha sonra bu peptidlerin daha küçük molekül ağırlıklı peptitlere parçalanması, olgunlaşmanın erken sayfasında SÇA bazında olgunlaşmanın hızlı artışını açıklamaktadır.

Çizelge 2. Sivas küp peynirlerinin olgunlaşma süresince olgunlaşma derecelerindeki değişimler (ortalama \pm standart sapma).

Table 2. The changes in ripening levels of Sivas küp cheeses during ripening period (mean土standard deviation)

\begin{tabular}{|c|c|c|c|c|c|c|}
\hline & \multicolumn{5}{|c|}{ Olgunlaşma süresi (Gün) / Ripening period (Day) } \\
\hline & & 0 & 15 & 30 & 60 & 90 \\
\hline \multirow{2}{*}{$\begin{array}{l}\text { SÇA } \\
(\%)\end{array}$} & $\mathrm{T}$ & $0,33 \pm 0,03^{a}$ & $0,63 \pm 0,01^{b x}$ & $0,71 \pm 0,02^{\mathrm{bx}}$ & $0,86 \pm 0,01 \mathrm{cx}$ & $1,36 \pm 0,10 \mathrm{dx}$ \\
\hline & $\mathrm{B}$ & $0,33 \pm 0,03 \mathrm{a}$ & $0,53 \pm 0,03^{\text {by }}$ & $0,63 \pm 0,01$ cy & $0,78 \pm 0,01 \mathrm{dy}$ & $0,93 \pm 0,01^{\text {ey }}$ \\
\hline \multirow{2}{*}{$\begin{array}{l}\text { TCA-ÇA } \\
(\%)\end{array}$} & $\mathrm{T}$ & $0,07 \pm 0,01^{\mathrm{a}}$ & $0,16 \pm 0,02^{\mathrm{bx}}$ & $0,22 \pm 0,03^{\mathrm{cx}}$ & $0,24 \pm 0,04 \mathrm{cx}$ & $0,25 \pm 0,04 \mathrm{cx}$ \\
\hline & B & $0,07 \pm 0,01^{\mathrm{a}}$ & $0,15 \pm 0,02^{b x}$ & $0,19 \pm 0,01 \mathrm{cx}$ & $0,20 \pm 0,01^{\mathrm{cdx}}$ & $0,22 \pm 0,03 \mathrm{dx}$ \\
\hline \multirow{2}{*}{$\begin{array}{l}\text { PTA-ÇA } \\
(\%)\end{array}$} & $\mathrm{T}$ & $0,03 \pm 0,01^{\mathrm{a}}$ & $0,06 \pm 0,0 \mathrm{bx}$ & $0,09 \pm 0,01 \mathrm{cx}$ & $0,20 \pm 0,03 \mathrm{dx}$ & $0,33 \pm 0,01^{\text {ex }}$ \\
\hline & B & $0,03 \pm 0,01^{\mathrm{a}}$ & $0,04 \pm 0,00^{\text {ay }}$ & $0,05 \pm 0,01$ by & $0,10 \pm 0,01$ су & $0,25 \pm 0,01 \mathrm{dy}$ \\
\hline \multirow{6}{*}{ 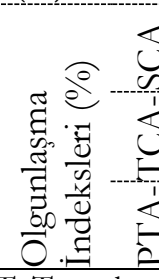 } & $\mathrm{T}$ & $10,96 \pm 0,87 a$ & $20,04 \pm 0,62^{\mathrm{bx}}$ & $20,62 \pm 0,62^{\mathrm{bcx}}$ & $21,66 \pm 0,66^{\mathrm{cdx}}$ & $22,47 \pm 1,18^{\mathrm{dx}}$ \\
\hline & B & $10,96 \pm 0,87 \mathrm{a}$ & $17,64 \pm 1,26^{\text {by }}$ & $19,14 \pm 0,81^{\mathrm{bcx}}$ & $19,51 \pm 0,55^{\mathrm{cdy}}$ & $20,89 \pm 0,45^{\mathrm{dx}}$ \\
\hline & $\mathrm{T}$ & $1,99 \pm 0,06^{\mathrm{a}}$ & $5,16 \pm 0,48^{\mathrm{bx}}$ & $6,50 \pm 0,42^{\mathrm{cx}}$ & $7,20 \pm 0,79 \mathrm{cx}$ & $7,53 \pm 0,070^{c x}$ \\
\hline & B & $1,99 \pm 0,06^{a}$ & $5,50 \pm 0,23^{\mathrm{bx}}$ & $6,00 \pm 0,28^{\text {bcy }}$ & $6,17 \pm 0,48^{c y}$ & $6,98 \pm 0,36 \mathrm{dy}$ \\
\hline & $\mathrm{T}$ & $0,90 \pm 0,21^{a}$ & $1,82 \pm 0,14 \mathrm{bx}$ & $2,94 \pm 0,23 \mathrm{cx}$ & $6,48 \pm 0,79 \mathrm{dx}$ & $10,69 \pm 0,31^{\mathrm{ex}}$ \\
\hline & B & $0,90 \pm 0,21^{a}$ & $1,37 \pm 0,19$ aу & $1,76 \pm 0,17$ by & $3,28 \pm 0,29$ су & $8,18 \pm 0,17$ dy \\
\hline
\end{tabular}

T: Toprakta olgunlaştırlan peynir (the cheese ripened being burried in soil)

B: Buzdolabı koşullarında olgunlaştırılan peynir (the cheese ripened under refrigerated conditions)

a-c: Aynı satırda farklı harflerle gösterilen ortalama değerler birbirinden farklıdır $(P<0.05)$.

a-c: The mean values shown in different letters on the same line are different $(P<0.05)$

$\mathrm{x}-\mathrm{y}$ : Aynı sütunda farklı harflerle gösterilen ortalama değerler birbirinden farklıdır $(P<0.05)$.

$x-y$ : The mean values shown in different letters in the same column are different $(P<0.05)$

\section{Peynirin duyusal özellikleri üzerine etkisi}

Olgunlaşma süreci sonunda yapılan duyusal değerlendirme de toprakta olgunlaşan ve buzdolabı koşullarında olgunlaşan peynirler benzer lezzet puanları almıştır. Buna karşın, görünüş, doku ve tüm izlenim açısindan ise toprakta olgunlaştrılan peynirler daha yüksek puanlar almıştır $(P<0.05$, Şekil 4$)$.

Duyusal değerlendirmede, panelistlerden puan düşüşlerinin nedenlerini belirtmeleri de istenmiştir. Panelistler tarafindan toprakta olgunlaştırılan peynirlerin renginin daha krem, buzdolabında koşullarında olgunlaştırılan peynirlerin renklerinin ise daha beyaz olduğu vurgulanmıştır. Bununla birlikte, panelistler tarafından buzdolabında olgunlaştırılan peynirlerde hafif kumlu yapı belirlenmiş ve toprakta olgunlaştırılan peynirlere kıyasla kırllganlığın daha fazla hissedildiği ifade edilmiştir. Toprakta olgunlaştırılan peynirler ise, buzdolabindakilere nazaran daha sert olarak algilanmıştır. Her iki grup da tuzlu olarak nitelendirilmiştir. Toprakta olgunlaştırılan peynirlerde hafif küfümsü lezzet varliğ1 da ifade edilmiştir. 


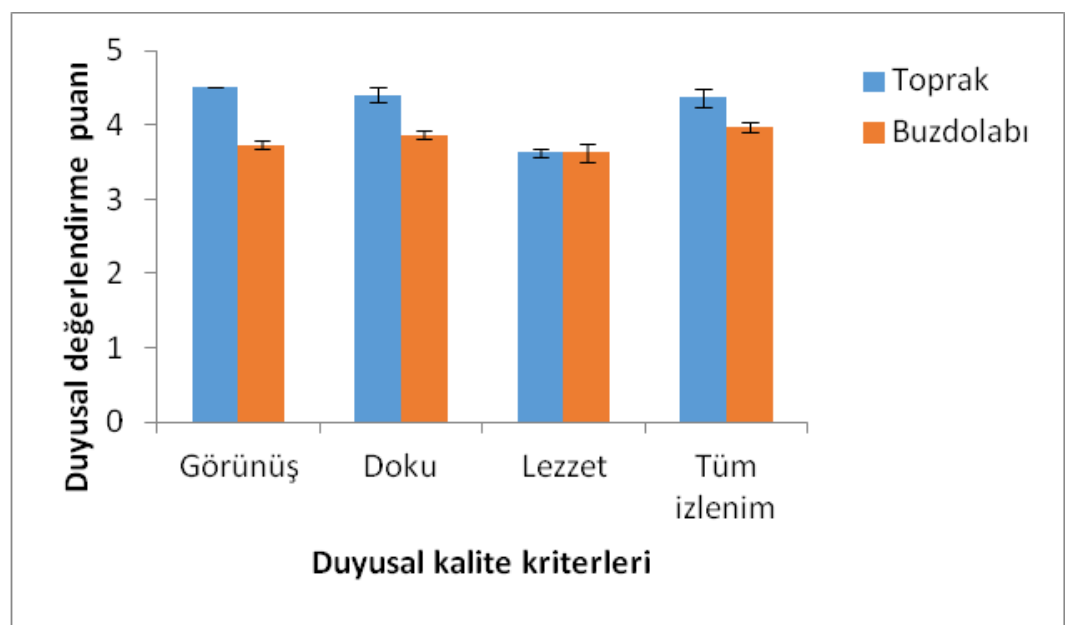

Şekil 4. Sivas küp peynirlerinin olgunlaşma süresi sonunda duyusal değerlendirme puanları Figure 4. Sensory scores of Sivas kïp cheeses at the end of ripening period

\section{SONUÇ}

Bu çalışmada, geleneksel yöntemle üretilen Sivas küp peynirinin plastik kavanozlarda toprağa gömülerek ve buzdolabında olgunlaştırilmasının, peynirin nitelikleri üzerinde yarattığ1 farkllıklar ortaya koyulmuştur. Her iki grupta da ambalajın ters kapatılıp peynir suyunun uzaklaştırılmasının devam etmesi nedeniyle, özellikle 15. günde kurumadde oranı önemli seviyede artmıştır. Kurumaddenin artış ile birlikte yağ ve protein oranlar1 artarken, peynir suyu ile tuzun uzaklaşması sebebiyle tuz oranı azalmıştır. Bu değissimler toprakta olgunlaştırılan peynirde daha belirgindir. Peynirlerde lipoliz ilk 15 gün içinde hızla gerçekleşmiş ve sonrasında devam etmemiştir. Örneklerde SÇA değerlerinde artış olgunlaşmanın başlangıcında, PTA-ÇA değerlerinde artış ise olgunlaşmanın ileri safhalarında daha belirgin seyretmiştir. Peynir örneklerinde olgunlaşma süresince maya ve küf sayısı artmıs, özellikle bu artşs toprakta olgunlaştırılan peynirde daha yüksek bulunmuştur. Özellikle ilk 15 günde toprakta olgunlaştırilan peynirde maya ve küf sayısındaki hızlı sıçrayış, topraktan bu mikroorganizmaların bulaştı̆̆ının göstergesi olarak değerlendirilmiştir. Olgunlaşmanın sonunda yapilan duyusal değerlendirmede, her iki grup da bütün kriterler açısından genel olarak iyi puanlar almıştır. Lezzet açısından benzer değerler almış, ancak doku, görünüş açısından toprakta olgunlaştırilan peynir nisbeten daha yüksek puanlar almıştır. Sonuç olarak, her iki olgunlaştırma yönteminin de Sivas küp peynirinde kullanılabileceği, ancak maya ve küf sayılarının yüksek olması nedeniyle üretim ve olgunlaştırma aşamalarının gıda güvenliği açısından da araştırılması gerekliliği ortaya koyulmuştur.

\section{TEŞEKKÜR}

Peynir üretiminin gerçekleştirilmesinde desteği için Türk Veteriner Hekimler Birliği Sivas Odası Başkanı Sayın Özcan Karataş'a ve laboratuvarlarını kullanımımıza açtıkları için Sivas Gıda Kontrol Laboratuvar Müdürlüğü'ne ve çalışanlarına çok teşekkür ederiz.

\section{KAYNAKLAR}

AOAC (2007a). Solids (total) in milk, AOAC Official Method 990.20, Official Methods of Analysis of AOAC International, 19th Edition, AOAC International, Gaithersburg, MA, USA.

AOAC (2007b). Nitrogen (total) in milk, AOAC Official Method 991.20, Official Methods of Analysis of AOAC International, 19 ${ }^{\text {th }}$ Edition, AOAC International, Gaithersburg, MA, USA.

AOAC (2007c). Acidity of milk, AOAC Official Method 947.05, Official Methods of Analysis of AOAC International, 19th Ed., AOAC International, Gaithersburg, MA, USA.

AOAC (2007d). Acidity of cheese, AOAC Official Method 920.124, Official Methods of 
Analysis of AOAC International, 19th Ed., AOAC International, Gaithersburg, MA, USA.

Ardö, Y. (1999). Evaluating proteolysis by analysing the $\mathrm{N}$ content of cheese fractions. In: Chemical Methods for Evaluating Proteolysis in Cheese Maturation. Bull Int Dairy Fed, 2 (337): 4-9.

Bütikofer, U., Ruegg, M., Ardö, Y. (1993). Determination of nitrogen fractions in cheese: Evaluation of collaborative study, Lebensm-Wiss. u- Tech, 26:271-275.

Coşkun, S., Konar, A., Güven, M. (2002). Küp (çanak) peynirlerinin özellikleri üzerine sütün yağ oranının ve pıhtıya uygulanan isıl işlemin etkileri. C.. Ü. Ziraat Faültesi Dergisi, 17 (2): 668.

Dervişoğlu M., Yazıc1, F. (2001). Ripening changes of Kulek cheese in wooden and plastic containers. J Food Eng, 48: 243-249.

Farkye, N. Y., Fox, P.F. (1990). Objective indices of cheese ripening. Trends Food Sci Technol, 1(2): 37-40.

FDA (2001). Bacteriological Analytical Manual, $8^{\text {th }}$ Edition. Chapter 18, BAM: Yeasts, Molds and Mycotoxins, New Hampshire, ABD.

Hayaloğlu, A.A., Topçu, A., Koca., N. (2011). Peynir analizleri. Bölüm 17, Peynir Biliminin Temelleri. A.A. Hayaloğlu, B. Özer (Ed). Sidaş Medya Ltd. Şti., İzmir, Türkiye, s: 489-562

Godinho, M., Fox, P.F. (1982). Ripening of Blue cheese: influence of salting rate on proteolysis. Milchwissenschaft, 37: 72-75.

Guinee, T.P. (2007). Introduction: what are the functions of $\mathrm{NaCl}$ in cheese? Chapter 39, Cheese Problem Solved. P:L.H. McSweeney (Ed). CRC Press, Woodhead Publishing Lmt. Cambridge, England. pp: 80-81.

Güler, M.B. (1999). Hatay Yöresi Sürk (Küflü Çökelek) ve Carra (Testi) peynirlerinin üretimi, özellikleri ve standardizasyon olanakları üzerine bazı araştırmalar. Çukurova Üniversitesi Fen Bilimleri Enstitüsü Gıda Mühendisliği Anabilim Dalı Doktora Tezi, Çukurova, Türkiye, $118 \mathrm{~s}$.

Güven, M., Karaca, O.B. (2004) Yozgat yöresinde üretilen Küp (Çanak) peynirlerinin yapım tekniği ve özellikleri, Geleneksel Gidalar Sempozyumu, 23-24 Eylül 2004, Van, Türkiye,

IDF (1981). Milk - Determination of fat content - Gerber Butyrometers. IDF Standard 105, International Dairy Federation, Brussels, Belgium.

IDF (1982). Determination of the total solid content (cheese and processed cheese). IDF Standard 4A, International Dairy Federation, Brussels, Belgium.

IDF (1988). Determination of salt content (Mohr method). IDF Standard 12B, International Dairy Federation, Brussels, Belgium.

ISO (2008). Milk and milk products - Guidance on sampling. 707/IDF 50, Organization for Standardization and International Dairy Federation, Switzerland.

Jarrett,W.D., Aston, J.W., Dulley, J.R. (1982). A simple method for free amino acids in Cheddar cheeses. Aust J Dairy Technol, 37: 55-58.

Kamber, U., Terzi, G. (2008). The traditional cheeses of Turkey: Central Anatolian Region, Food Rev Int, 24: 74-94.

Kaptan, B. (2016). Prevalence of Listeria spp and L.monocytogenes in home made pottery cheese. Tekirdă Ziraat Fakültesi Dergisi, 13(1): 80-87.

Koca, N. (2002). Bazı yağ ikame maddelerinin yağ1 azaltılmış kaşar peynirinin nitelikleri üzerine etkileri. E.Ü. Fen Bilimleri Enstitüsü, Bornova, İzmir, 227 sayfa.

Karahadian, G., Lindsay, R.C. (1987). Integrated roles of lactate, ammonia and calcium in texture development of mold surface ripened cheeses. $J$ Dairy Sci 70: 909-918.

Koluaçı1k, H.A. (2014). Toprak ambalajda olgunlaştırilan geleneksel küp peynirlerinde Aflatoksin M1 düzeyinin belirlenmesi. Namık Kemal Üniversitesi Fen Bilimleri Enstitüsü, Yüksek Lisans Tezi, Tekirdağ, Türkiye, $30 \mathrm{~s}$.

Nunez, M., Garsia-Aser, C., Rodriguaz-Martin, M.A., Medina, M., Gaya, P. (1986). The effect of ripening and cooking temperatures on proteolysis and lipolysis in Manchego Cheese. Food Chem, 21: 115-123. 
Öztürk, G.F. (1993). Kaşar peynirlerinin olgunlaştırılmasının hızlandırılması üzerine nötral proteaz ve nötral proteaz-lipaz enzim kombinasyonunun etkisi. Ege Üniversitesi Fen Bilimleri Enstitüsü, Doktora Tezi, İzmir, Türkiye, $105 \mathrm{~s}$.

Pekel, M., Korkoğlu, M. (2009). Sivas yöresinde üretilen Küp peynirinin mikrobiyolojik, kimyasal kalitesi ve küf florasının belirlenmesi. Anadolu Tarm Bilimleri Dergisi, 24(1): 1-7.
Trieu-Cout, P., Gripon, J.C. (1982). A study of proteolysis during camembert cheese ripening using isoelectrofocusing and two-dimensional electrophoresis. J Dairy Res, 49: 501-510.

TSE (1978). Peynirde yağ miktarı tayini, No:3046, Türk Standartlar1 Enstitüsü, Ankara. 